Www.jmscr.igmpublication.org

Impact Factor (SJIF): 6.379

Index Copernicus Value: 79.54

ISSN (e)-2347-176x ISSN (p) 2455-0450

crossrefDOI: https://dx.doi.org/10.18535/jmscr/v6i9.183

Journal Of Medical Science And Clinical Research

IGM Publication

An Official Publication of IGM Publication

$\underline{\text { Research Article }}$

\title{
Development of Health System in India: A Brief Overview of Recommendations of the various Committees Since 1947 To 2015
}

\author{
Author \\ Madan Mohan Laddunuri*
}

\begin{abstract}
WHO defines 'public health' as the science and art of promoting health, preventing disease and prolonging life through the organized efforts of the Society. Public health is a social and political concept aimed at improving health, prolonging life and quality of life among whole populations through health promotion, disease prevention and other forms of health interventions.

According to World Health Organization (WHO), a well-functioning health system working in harmony is fabricated on trained and motivated health workers, a well-maintained infrastructure, and a consistent supply of medicines and technologies, backed by sufficient funding, well-built health plans and evidencebased policies. A health system consists of all organizations, people and actions whose primary goal is to promote, restore or maintain health. The overall health systems objective is to improve population health outcomes in an impartial way without burden people with health care expenditure.

India's health care system was carefully prepared at the time of Independence (1947) to make available primary, preventive, and curative health care within a reachable distance of the population even in isolated, rural areas. Health care services at the primary, secondary and tertiary level, run mainly by State Governments, afford free or very low cost medical services. Over the past seventy years (since 1947), public health infrastructure and services have undergone significant changes and massive expansion in scale and nature based on recommendations by a number of expert committees.
\end{abstract}

Keywords: Development, Public Health Systems, Various Committees.

\section{Introduction}

WHO defines 'public health' as the science and art of promoting health, preventing disease and prolonging life through the organized efforts of the society. ${ }^{1} \quad$ Public health is a social and political concept aimed at improving health, prolonging life and quality of life among whole populations through health promotion, disease prevention and other forms of health interventions. ${ }^{2}$

According to World Health Organization (WHO), a well-functioning health system working in harmony is fabricated on trained and motivated health workers, a well-maintained infrastructure, and a consistent supply of medicines and technologies, backed by sufficient funding, wellbuilt health plans and evidence-based policies. ${ }^{3} \mathrm{~A}$ health system consists of all organizations, people and actions whose primary goal is to promote, restore or maintain health. ${ }^{4}$ The overall health systems objective is to improve population health outcomes in an impartial way without burden people with health care expenditure. ${ }^{5}$ 
The development of Health Care system in India

India's health care system was carefully prepared at the time of Independence (1947) to make available primary, preventive, and curative health care within a reachable distance of the population even in isolated, rural areas. ${ }^{6}$ The health care system in India, at present, has a three-tier composition to offer health care services to its people. ${ }^{7}$ Health care services at the primary, secondary and tertiary level, run mainly by State Governments, afford free or very low cost medical services.

Since independence, several governments appointed Committees and Commissions examined issues and challenges which health sector is facing. The purpose of these ad-hoc committees formed from time to time is to review the current situation regarding public health status in the country and suggest further course of action in order to accord the best of health care to the people ${ }^{8}$. Over the past seventy years (since 1947), public health infrastructure and services have undergone significant changes and massive expansion in scale and nature based on recommendations by a number of expert committees. ${ }^{9}$

\section{Recommendations of the various committees}

The Table 1 below highlights the salient findings and recommendations of the various committees since 1947.

Table 1 Major findings and recommendations of the various committees of the Government of India since 1947

\begin{tabular}{|c|c|c|}
\hline Year & $\begin{array}{l}\text { Name of the } \\
\text { committee/ } \\
\text { programme }\end{array}$ & Major findings and recommendations \\
\hline 1948 & $\begin{array}{l}\text { Sokhey Committee } \\
\text { Report on National } \\
\text { Health policy } 10\end{array}$ & $\begin{array}{l}\text { The National Planning Committee (NPC) set up by the Indian } \\
\text { National Congress in } 1948 \text { under the chairmanship of Colonel S. } \\
\text { Sokhey stated that the maintenance of the health of the people was } \\
\text { the prime responsibility of the State, and the combination of } \\
\text { preventive and curative functions in a only one state agency was } \\
\text { emphasized }{ }^{11}\end{array}$ \\
\hline 1952 & $\begin{array}{l}\text { Community } \\
\text { Devlopment }^{12}\end{array}$ & $\begin{array}{l}\text { CDP was a multipurpose programme which covering health and } \\
\text { sanitation (through the establishment of Primary Health Care } \\
\text { Centers and Sub-Centers) and other related sectors, including } \\
\text { agriculture, education, social welfare and industries. Each and every } \\
\text { Community Development Block (CDB) consists of } 100 \text { villages } \\
\text { with total population of } 100,000 \text {. }\end{array}$ \\
\hline 1962 & $\begin{array}{l}\text { Mudaliar Committee } \\
\text { on Health and } \\
\text { Planning }{ }^{13}\end{array}$ & $\begin{array}{l}\text { The main recommendation of this committee was to limit the } \\
\text { population served by primary health centers to } 40,000 \text { with the } \\
\text { improvement in the quality of health care provided by these centers. } \\
\text { Also provision of one basic health worker per } 10,000 \text { population } \\
\text { was recommended. }\end{array}$ \\
\hline 1966 & $\begin{array}{l}\text { Mukherji Committee } \\
\text { on essential Health } \\
\text { Service }{ }^{14}\end{array}$ & $\begin{array}{l}\text { The committee worked out the composition and organization of } \\
\text { basic health services, which is provided at Block level. This } \\
\text { committee strongly recommended the importance of strengthening } \\
\text { of the supervisory levels to correspond to the strengthening of the } \\
\text { base organization. } 15\end{array}$ \\
\hline 1967 & $\begin{array}{l}\text { Jungalwalla } \\
\text { Committee on } \\
\text { Integration of Health } \\
\text { Services } 16\end{array}$ & $\begin{array}{l}\text { The committee recommended the importance of integration from the } \\
\text { highest level to lowest level in the services, organization and } \\
\text { personnel. Public Health programs should be put under charge of a } \\
\text { single administrator at all levels of hierarchy by adopting - The } \\
\text { Unified Cadre, Common Seniority, recognition of extra }\end{array}$ \\
\hline
\end{tabular}




\begin{tabular}{|c|c|c|}
\hline & & $\begin{array}{l}\text { qualifications, equal pay for equal work, special pay for special } \\
\text { work, abolition of private practice by government doctors. }\end{array}$ \\
\hline 1973 & $\begin{array}{lr}\text { Kartar } & \text { Singh } \\
\text { Committee } & \text { on } \\
\text { Multipurpose } & \text { Health } \\
\text { Workers } & \end{array}$ & $\begin{array}{l}\text { The committee recommended the integration of peripheral workers } \\
\text { into a single cadre of multipurpose workers. Also it recommended } \\
\text { the organizational change with respect to PHCs and SCs - one PHC } \\
\text { to be established for every } 50,000 \text { population. } \\
\text { Each PHC to be divided into } 16 \text { SCs each for a population of } 3,000- \\
3,500 \text {. Each SC to be staffed by a team of one male and one female } \\
\text { health worker. The work of } 3-4 \text { health workers to be supervised by } \\
\text { one Health Assistant. }\end{array}$ \\
\hline 1975 & $\begin{array}{l}\text { Shrivastav } \\
\text { Committee } \\
\text { Medical Education } \\
\text { and Support health } \\
\text { workers } 18\end{array}$ & $\begin{array}{l}\text { Recommendations of the committee: Creation of groups of par- } \\
\text { medical professional and semi-professional health workers from } \\
\text { within the community. Establishment of three cadres of health } \\
\text { workers between community level workers and doctors at PHC. } \\
\text { Development of "Referral Service" by developing connections } \\
\text { between the primary health center and higher level referral and } \\
\text { service centers like taluka, district, regional and medical college } \\
\text { hospitals. Establishment of a Health and medical Education } \\
\text { Commission to bring reforms in health and medical education at } \\
\text { universities. }\end{array}$ \\
\hline 1997 & $\begin{array}{ll}\text { Rural } & \text { Health } \\
\text { Scheme: } & \text { Village } \\
\text { Health } & \text { Guides } \\
\text { scheme } & \end{array}$ & $\begin{array}{l}\text { Village Health Guide (VHG) scheme: According to this scheme, the } \\
\text { village community selects a volunteer team from the village, } \\
\text { predominantly women, who was instructed short term training for } \\
\text { the work. VHG links between the community and the Government } \\
\text { Health System. }{ }^{20} \text { Volunteer provides health education and creates } \\
\text { knowledge of Maternal and Child Health and Family Welfare } \\
\text { Services. }\end{array}$ \\
\hline 1978 & $\begin{array}{l}\text { Alma Ata } \\
\text { Declaration: } \\
\text { For All by 2000) }\end{array}$ & $\begin{array}{l}\text { Recommendations of Alma Ata Declaration: Primary health care } \\
\text { should include education relating to health problems and techniques } \\
\text { of identifying, preventing and controlling of them; promotion of } \\
\text { nutritional food and safe water supply and basic sanitation; } \\
\text { maternal and child health care, family planning; immunization; } \\
\text { prevention of local diseases; provision of drugs. }\end{array}$ \\
\hline 1980 & $\begin{array}{l}\text { ICSSR and ICMR - } \\
\text { ("Health for all: An } \\
\text { Alternate Strategy) }\end{array}$ & $\begin{array}{l}\text { The report of ICSSR and ICMR recommended the formulation of a } \\
\text { wide-ranging national health policy which includes environment, } \\
\text { education, and nutrition, socio-economic, preventive and curative } \\
\text { dimensions. }\end{array}$ \\
\hline 1983 & $\begin{array}{lr}\text { Mehta } & \text { Committee } \\
\text { regarding } & \text { Medical } \\
\text { Education } & \end{array}$ & $\begin{array}{l}\text { The Mehta committee mainly re-evaluated the medical education } \\
\text { and discussed specifically about inadequate Health manpower in } \\
\text { India. In addition, It also suggested establish, a commission for } \\
\text { medical universities and colleges. }\end{array}$ \\
\hline 1987 & $\begin{array}{l}\text { Bajaj Committee on } \\
\text { health manpower } \\
\text { planning, production } \\
\text { and managemet }\end{array}$ & $\begin{array}{l}\text { The major recommendations Bajaj Committee are: 1.Formulation } \\
\text { of national medical education policy. 2. Formulation of national } \\
\text { health workers policy.3.Devlopmnt of an Educational Commission } \\
\text { for Health Sciences with the coordination with UGC. } \\
\text { 4.Establishment of health science universities in various states. } \\
\text { 5.To develop Vocational courses related to health fields. }\end{array}$ \\
\hline 1996 & $\begin{array}{l}\text { Bajaj Committee on } \\
\text { Public } \quad \text { Health } \\
\text { Systems }\end{array}$ & $\begin{array}{l}\text { The Key recommendations are to review National Health Policy, } \\
\text { Establishment of health impact assessment cell, surveillance of } \\
\text { polluted areas, uniform public health Act, find out alternative } \\
\text { strategy to strengthening of health services and research, joint }\end{array}$ \\
\hline
\end{tabular}




\begin{tabular}{|c|c|c|}
\hline & & $\begin{array}{l}\text { council of health, family welfare, establishing an apex technical } \\
\text { advisory board, Establishment of regional schools of public health } \\
\text { along manpower, planning, production and management of } 1987 \text {. }\end{array}$ \\
\hline 2000 & $\begin{array}{l}\text { National Population } \\
\text { Policy (NPP) }\end{array}$ & $\begin{array}{l}\text { The immediate objective of NPP was to deal with the contraception, } \\
\text { health care infrastructure and health staff and to provide basic } \\
\text { reproductive and childcare services. It visualize the development of } \\
\text { one-stop integrated and coordinated basic reproductive and child } \\
\text { health services delivery at the village level through a partnership of } \\
\text { the government with non-governmental organizations. }\end{array}$ \\
\hline 2002 & $\begin{array}{l}\text { Second National } \\
\text { Health Policy }^{27}\end{array}$ & $\begin{array}{l}\text { The goals set by Second National Health Policy are: Eradication of } \\
\text { Polio by } 2005 \text {, Elimination Kala Azar by } 2010 \text {, Eradication of } \\
\text { Leprosy by 2005, Elimination Lymphatic Filariasis by } 2015 \text {, } \\
\text { Reduction of half of Mortality related to TB, Malaria, other vector } \\
\text { and water borne diseases by } 2010 \text {. Reduction of Infant mortality to } \\
30 / 100 \text { and maternal mortality ratio to } 100 \text { per } 100,000 \text { by } 2010 \text {. } \\
\text { Raise the utilization of public health facilities from }<20 \% \text { to }>75 \% \\
\text { by } 2010 \text {. Increase health expenditure by Government from existing } \\
0.9 \% \text { GDP to } 2 \% \text { GDP by } 2010 \text {. Raise share of central grants to } \\
25 \% \text { of total health spending by } 2010 \text {. } \\
\text { Increase state sector health spending from } 5.5 \% \text { to } 7 \% \text { of budget by } \\
2005 \text {. }\end{array}$ \\
\hline 2005 & $\begin{array}{lr}\text { National } & \text { Rural } \\
\text { Health } & \text { Mission } \\
(\text { NRHM) } & \end{array}$ & $\begin{array}{l}\text { The National Rural Health Mission main objective to provide } \\
\text { universal access to equitable, affordable and quality health care to } \\
\text { community. Human resource requirement under NRHM has stepped } \\
\text { up drastically, in view of renewed commitment to universal } \\
\text { coverage. The challenges involved in training, recruitment, } \\
\text { placement and motivation of health workers across the country } \\
\text { cannot be neglected, if universal coverage is to be attained. }\end{array}$ \\
\hline 2015 & $\begin{array}{l}\text { National } \\
\text { Policy }^{29}\end{array}$ & $\begin{array}{l}\text { The most important goal of the Policy is: The highest level of good } \\
\text { health and social-well-being, through a preventive health care in all } \\
\text { developmental policies, and universal access to good quality health } \\
\text { care services. } \\
\text { The major goal of the policy are: Improve health status of the } \\
\text { population through proper policy in all sectors and expand } \\
\text { preventive, curative, promotive and rehabilitative services provided } \\
\text { by the public health sector. } \\
\text { Guarantee universal availability and accessibility of free, wide- } \\
\text { ranging primary health care services, including, maternal, child, } \\
\text { reproductive and adolescent health and communicable and non- } \\
\text { communicable diseases in the population. } \\
\text { Facilitate universal access to free necessary drugs, diagnostics, } \\
\text { emergency ambulance services, and emergency medical and } \\
\text { surgical care services in public health facilities, for all sections of } \\
\text { the population. Make possible health care systems more effective, } \\
\text { rational, safe, affordable and ethical. }\end{array}$ \\
\hline
\end{tabular}

\section{Conclusion}

Since independence, several governments appointed Committees and Commissions examined issues and challenges which health sector is facing. The purpose of these ad hoc committees formed from time to time is to review the current situation regarding public health status in the country and suggest further course of action in order to accord the best of health care to the people. 


\section{References}

1. World Health Organization, World Report on Knowledge for Better Health Strengthening Health Systems, 2004. <http://www.who.int/rpc/meetings/en/world _report_on_knowledge_for_better_health2.p df>, Accessed June 19, 2016.

2. World Health Organization. Health Promotion Glossary, 1998. WHO/HPR/HEP/98.1.

$<$ http://www.who.int/healthpromotion/about /HPR\%20Glossary\%201998.pdf >. Accessed June 19, 2016.

3. Health systems: key expected results, World Health Organization. $<$ http://www.who.int/healthsystems/about/pr ogress-challenges/en/>. Accessed June 07, 2016.

4. The world health report 2000 - Health systems: improving performance. <http://www.who.int/whr/2000/en/whr00_e n.pdf?ua=1>. Accessed June 07, 2016.

5. WHO - India. Health systems. <http://www.searo.who.int/india/topics/healt hsystems/en/>. Accessed June 07, 2016.

6. Kalpana Jain, WEIGO working paper (Social protection) on "Health financing and delivery in India: an overview of selected schemes, Women in informal employment globalizing and organizing. $<$ http://wiego.org/sites/wiego.org/files/publi cations/files/Jain-Health-FinancingIndiaWIEGO-WP29.pdf.

7. Majumder A and Upadhyay V. An analysis of the primary health care system in India with focus on reproductive health care services. Artha Beekshan 2004;12(4): 2938 .

<http://amlan.co.in/yahoo_site_admin/assets /docs/Amlan_First_Paper_Health_Careamla ncoin. 16115720

8. http://shodhganga.inflibnet.ac.in/bitstream/1 0603/7296/11/11_chapter\%202.pdf,

Accessed June 19, 2015.
9. Kumar V. Government of India: Committees and Commissions in India, Vol. 7: 1996.

10. Report of National Planning Committee Sub Committee on National Health, Government of India, 1948.

11. Banerji D. Health and family planning services in India: An epidemiological, socio-cultural and political analysis and a perspective. Lok Paksh, New Delhi, 1985.

12. Bhattacharya S.N. Community Development- An Analysis of the Programme in India, Community Development Journal, 1971, 6(1), 51-52.

13. Report of the Health Survey and Planning Committee, Ministry of Health, Government of India, New Delhi, 1961.

14. Mukerji Committee Report on Basic Health Services, 1966. Director General of Health Services, Ministry of Health, Government of India.

<http://www.communityhealth.in/ commun 26/wiki/images/6/6e/Mukerji_Committee_re p ort_1966.PDF.pdf>; Accessed June 07, 2015.

15. Report of Mukerji Committee on Basic Health Services, Government of India, New Delhi, 1966.

16. Report of the committee on Integration of Health Services, Directorate General of Health Services, New Delhi, March 1967.

17. Report of the Committee of Multipurpose Workers under Health and Family Planning Programme Ministry of Health and Family Planning, New Delhi, 1973

18. Report of the group on Medical Education and Support Manpower, Health Services and Medical Education -A programme for immediate Action, Ministry of Health and Family Planning, Government of India, New Delhi, 1975.

19. Report of the National Commission on Macroeconomics and Health (Chapter 7), Ministry of Health and Family Welfare, Government of India, 2005. 
20. Satihal D.G, Rajarama K.E.T. Evaluation of Village Health Guide Scheme, Belgaum District, Karnataka, Report prepared for the Ministry of Health and Family Welfare, Government Of India, New Delhi, 2000.

21. Declaration of Alma-Ata 1978, Primary Health Care. Report of the International Conference on Primary Health Care, AlmaAta, USSR, 6-12 September 1978. <http://www.unicef.org/about/history/files/ Alma_Ata_conference_1978_report.pdf $>$;

Accessed June 19, 2016.

22. Health for all: An alternative strategy. Pune: Indian Institute for Education; 1980. ICSSR and ICMR.

23. Report of the Medical Education Review Committee, Ministry Of Health and Family Welfare, Government of India, 1983.

24. Report of the Expert Committee on Health Manpower Planning, Production and Management, Ministry of Health and Family Welfare, Government of India, New Delhi, 1987.

25. Report of the Expert Committee on Public Health System, Ministry of Health and Family Welfare, Government of India, New Delhi, 1996.

26. National Population Policy 2000, Ministry of Health and Family welfare, Government of India, New Delhi, 2000.

27. National Population Policy 2002, Ministry of Health and Family welfare, Government of India, New Delhi, 2002. <http://www.mohfw.nic.in/WriteReadData/l 892s/18048892912105179110National\%20

Heal th\%20policy-2002.pdf >; Accessed June 19, 2016.

28. National Rural Health Mission, Frame work for implementation, 2005-12, Ministry of Health and Family Planning, New Delhi, April 2005.

29. National Health Policy 2015.Draft, Ministry of Health and Family Welfare Government of India, 2015.Available from: www.mohfw.nic.in. 